\title{
Lessons from health during the transition from communism
}

\author{
Martin McKee, Ellen Nolte \\ Countries that are in transition from communism provide the opportunity for comparing the effects \\ on health of communist and democratic political systems
}

European Centre on Health of

Transition, London School of Hygiene and Tropical Medicine, London WC1E 7HT Martin McKee professor of European public health

Ellen Nolte senior lecturer Correspondence to: M McKee martin.mckee@ lshtm.ac.uk

If democracy really is good for health, then the countries of central and eastern Europe are obvious places to look for an effect. These countries were part of the Soviet bloc for several decades of the 20th century before adopting, to various degrees, democratic governments in the 1990s. Their experience provides a wealth of natural experiments.

Between the 1920s and '50s the communist system achieved much. In 1917, the Bolsheviks inherited a health situation from imperial Russia that was appalling. Faced with epidemic typhus, Lenin noted that "if communism does not destroy the louse, the louse will destroy communism." ${ }^{\prime \prime}$ One clear political commitment was to improve the health of the population, and in many ways this was successful. Basic health services were provided to a widely dispersed population, endemic diseases were controlled or eradicated, and health outcomes improved noticeably. All of these gains took place in the absence of a semblance of democracy. Yet they could not be sustained. By the 1960s, the financial demands placed by the military and industrial complex on a failing economy meant that the Soviet Union could not begin to aspire to implement the innovations being developed in the West. As a consequence, life expectancy in the Soviet Union slipped ever further behind the West. ${ }^{2}$ Although less obvious, the same phenomenon was becoming apparent in the Soviet satellite states of central and eastern Europe. ${ }^{3}$

No single reason was accountable for the worsening health. The immediate causes were cardiovascular disease, injuries, and some cancers. The lack of any mechanism for expression of popular discontent, combined with a sense of futility among many people, underlies the failure of the system to respond to the increase in disease, exacerbated, in the Soviet Union, by the domination of science by communist ideology. ${ }^{4}$ Thus, although an absence of democracy may have facilitated policies to improve health in the 1940s and

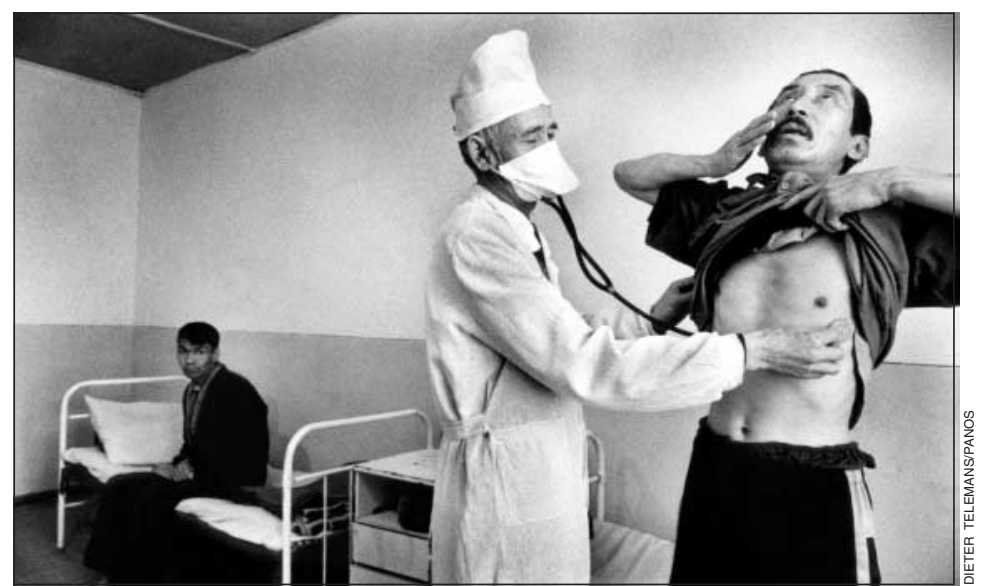

The impoverished town of Muyanuk on the Aral Sea has the highest tuberculosis rate in the former Soviet Union '50s, it also impeded the development of effective responses to the new challenges of the ' 60 s and ' $70 \mathrm{~s}$.

From 1989 onwards, the communist regimes started to fall. The democratic credentials of the new governments varied, however. A fully functioning democracy involves more than just elections. It includes the existence of a free press, an independent legal system, guaranteed rights for opposition parties and minorities, and measures to tackle corruption. These took time to develop in some countries. Several countries that emerged from the Soviet Union, such as Belarus, Turkmenistan, and Uzbekistan, are no closer now to having these conditions than they were in 1991.

\section{What has happened since the collapse of communism?}

What has happened to health since the transition from communism? The experiences of these countries certainly seem to offer support for the hypothesis advanced by Franco et al. ${ }^{5}$ Those countries that were most successful in making the transition to democracy saw some of the greatest gains in life expectancy. Although most experienced a transient deterioration, with increased traffic and other injuries typically playing a part, sustained improvements soon followed in former East Germany, ${ }^{6}$ Poland, and Czechoslovakia (with continued progress in its two successor states). ${ }^{7}$ Yet the improvement was delayed for a few years in Hungary, even though the transition to democracy was no less effective than in countries to the north. Further east, in Bulgaria and Romania, the improvement was also delayed. ${ }^{8}$ This is, however, consistent with the slower development of functioning democratic systems in those countries.

Some support for Franco et al's hypothesis can be seen in states that emerged from the Soviet Union. ${ }^{5}$ In most of this region, democracy has secured only a tenuous foothold. The region also has the dubious distinction of being one of only two major areas where life expectancy is falling, the other being sub-Saharan Africa. ${ }^{9}$ The only exceptions are the Baltic states, three countries (now part of an enlarged European Union) that can be considered fully functioning democracies.

\section{Democracy or open markets?}

But are these changes a consequence of democracy or something else, such as the opening of economic markets? This is a crucial question. In some countries, such as Russia and Ukraine, democratic changes are being reversed and official commentators are looking favourably on the experience of China, where market reforms have proceeded in the absence of democracy.

Certainly many of the early improvements in central Europe reflected the new opportunities created by the opening of borders to international trade, which allowed people to consume a healthy diet. ${ }^{10}$ Yet the opening of markets has not been uniformly beneficial. Franco et al 


\section{Summary points}

Countries in transition from communism provide valuable information on the effects of democracy on health

Health improvements have been greatest in countries that have embraced democracy most enthusiastically

Lack of democratic structures in some countries of the former Soviet Union acts as a barrier to the implementation of healthy public policies

argue that democracy may be the best protection against the harmful effects of globalisation. This view is supported by, for example, the tobacco industry's exploitation of the situation in countries with widespread corruption and a lack of functioning democratic systems, ${ }^{11}$ contrasted with the industry's growing record of failure when faced by democratic governments.

So does the experience of the former Soviet bloc support the hypothesis that democracy is good for health? Although there have been winners and losers among populations everywhere, regardless of the progress towards democracy that their governments have made, ${ }^{12}$ it seems that democracy is good for health.

Contributors: MMcK and EN drafted the paper. MMcK is guarantor.

Competing interests: None declared.

1 Vinogradov NA, Strashun ID. Health protection of the workers of the Soviet Union. Moscow: Medgiz, 1947.

2 Andreev EM, Nolte E, Shkolnikov VM, Varavikova E, McKee M. The evolving pattern of avoidable mortality in Russia. Int J Epidemiol 2003;32:437-46

3 Chenet L, McKee M, Fulop N, Bojan F, Brand H, Hort A, et al. Changing life expectancy in central Europe: is there a single reason? J Public Health Med 1996:18:329-36.

4 Krementosov NL. Stalinist science. Princeton, NJ: Princeton University Krementosov

5 Franco A, Alvarez-Dardet C, Ruiz MT. Effect of democracy on health: ecological study. BMJ 2004;329:1421-4.

6 Nolte E, Shkolnikov V, McKee M. Changing mortality patterns in East and West Germany and Poland. II: short-term trends during transition and in the 1990s.J Epidemiol Community Health 2000;54:899-906.

7 McKee M, Adany R, MacLehose L. Health status and trends in candidate countries. In: McKee M, MacLehose L, Nolte E, eds. Health policy and European Union enlargement. Buckingham: Open University Press, 2004:24-42.

8 Dolea C, Nolte E, McKee M. Changing life expectancy in Romania following the transition. J Epidemiol Community Health 2002;56:444-9.

9 McMichael AJ, McKee M, Shkolnikov V, Valkonen V. Mortality trends and setbacks: global convergence or divergence? Lancet 2004;363:1155-9.

10 Zatonski WA, McMichael AJ, Powles JW. Ecological study of reasons for sharp decline in mortality from ischaemic heart disease in Poland since 1991. BMJ 1998;316:1047-51

11 Gilmore A, McKee M. Tobacco and transition: an overview of industry investments, impact and influence in the former Soviet Union. Tob Control 2004; $13: 136-42$.

12 McKee M. Winners and losers. Int J Epidemiol 2003;32:1087-8.

\section{Transatlantic divide in publication of content relevant to developing countries}

Asad J Raja, Peter A Singer

Although 112 countries now receive 2200 medical journals free or at reduced prices, improving access to information on obesity is of little value to physicians treating patients dying of malnutrition. Ninety per cent of the US\$70bn (£38bn; €54bn) spent annually on health research is focused on the diseases of $10 \%$ of the world's population. ${ }^{1}$ Researchers in eight industrialised countries produce almost $85 \%$ of the world's leading science; 163 countries, including most of the developing world, account for less than $2.5 \% .^{2}$ Less than $8 \%$ of articles published in the six leading tropical medicine journals in 2000-2 were generated exclusively by scientists from developing countries. ${ }^{3}$ Medical journals cannot single handedly right these inequities, but they have an important role to play. The $B M$ Js ethics committee identified publication of content relating to developing countries as an important ethical issue to examine. Our objectives were to review the relevance of the contents of four leading medical journals to developing countries, compare the journals, and observe trends.

Content relevant to developing countries of four leading medical journals in January 2002 and January 2003. Values are numbers of articles relevant to developing countries/all published articles in that category (percentages)

\begin{tabular}{|c|c|c|c|c|c|c|}
\hline Journal & $\begin{array}{l}\text { Original research } \\
\text { articles }\end{array}$ & $\begin{array}{l}\text { Review } \\
\text { articles }\end{array}$ & Editorials & Letters & $\begin{array}{l}\text { Commentaries, perspectives, } \\
\text { and education and debate }\end{array}$ & $\begin{array}{c}\text { News and } \\
\text { miscellaneous items }\end{array}$ \\
\hline \multicolumn{7}{|l|}{ Lancet } \\
\hline January 2002;359(9300-3) & 7/39 (18) & $0 / 1 \quad(0)$ & $2 / 4 \quad(50)$ & $16 / 53(30)$ & $6 / 43$ (14) & 19/94 (20) \\
\hline January 2003;361(9351-4) & $2 / 37(5)$ & $1 / 4(25)$ & $3 / 4(75)$ & $14 / 62(23)$ & $20 / 55(36)$ & $12 / 65(18)$ \\
\hline \multicolumn{7}{|l|}{ BMJ } \\
\hline January 2002;324(7328-31) & $8 / 23(35)$ & $3 / 7 \quad(43)$ & $7 / 19(37)$ & $17 / 46(37)$ & $7 / 12(58)$ & 24/166 (14) \\
\hline January 2003;326(7379-82) & $5 / 25(20)$ & $2 / 11(18)$ & $5 / 20(25)$ & $7 / 41(17)$ & $3 / 9(33)$ & $22 / 136(16)$ \\
\hline \multicolumn{7}{|l|}{ JAMA } \\
\hline $\begin{array}{c}\text { January 2002;287(1-4) } \\
\end{array}$ & $1 / 18(5)$ & $0 / 8(0)$ & $0 / 9(0)$ & $1 / 54(2)$ & $1 / 15 \quad(7)$ & 9/76 (12) \\
\hline January 2003;289(1-4) & $0 / 14(0)$ & $0 / 3(0)$ & $0 / 7 \quad(0)$ & $1 / 17(6)$ & $0 / 9(0)$ & $4 / 88$ (5) \\
\hline \multicolumn{7}{|l|}{ New England Journal of Medicine } \\
\hline January 2002;346(1-5) & $2 / 20(10)$ & $0 / 5(0)$ & $1 / 15 \quad(7)$ & $4 / 26(15)$ & $0 / 20(0)$ & $0 / 11(0)$ \\
\hline January 2003;348(1-5) & $2 / 22(9)$ & $0 / 4(0)$ & $0 / 11(0)$ & $0 / 38(0)$ & $1 / 5(20)$ & $0 / 38 \quad(0)$ \\
\hline
\end{tabular}

Department of Surgery, Aga Khan University, Nairobi, Kenya

Asad J Raja Mohammed Bhai professor

Joint Centre for Bioethics, University of Toronto, Toronto, ON, Canada M5G 1L4 Peter A Singer Sun Life financial chair and director Correspondence to: A J Raja Asad.Raja@ akhskenya.org BMJ 2004;329:1429-30 